\title{
MATERIALS RESOURCE CENTER: Positions Available
}

\section{MULTIPLE POSTDOCTORAL POSITIONS: BATTERIES, SUPERCAPACITORS, PEM FUEL CELLS, CORROSION RESISTANT COATINGS FOR NUCLEAR, AND HEAVY OIL CORROSION - FOULING. \\ We have several openings in the broad areas of nanomaterials for renewable and conventional energy storage, generation and efficiency. Projects may be focused on a combination of synthesis, testing, modeling, and analysis via tools like TEM and FIB. Metallurgists, materials scientists, chemists and electrochem- ists are encouraged to apply. The start dates are April 1st or later. \\ If interested please send a CV and the contact information for references to: David Mitlin \\ Department of Chemical and Materials Engineering 7th Floor \\ 9107116 Street \\ University of Alberta Edmonton \\ Alberta, T6G 2V4 \\ or Email: david.mitlin3@gmail.com \\ * D.M. is also affiliated with the National Institute for Nanotechnology (NINT) $\mathrm{NRC}$ located in Edmonton AB. \\ http://www.ualberta.ca/CMENG/Mitlin-Group/}

\section{Cut through the clutter... use the TMS Marketplace! Everything You Need for One-Stop Shopping...}

- Up to-date inventories from the leading materials suppliers

- Clutter-free searching for quick results

- Downloadable to your desktop for easy access

Visit www.tms.org and select the TMS Marketplace to access the most up-to-date information on vendors who support the metals and materials industries.

\section{EIH}

Eidgenössische Technische Hochschule Zürich

Swiss Federal Institute of Technology Zurich

\section{Professor of Soft Materials}

The Department of Materials at ETH Zurich (www.mat.ethz.ch) invites applications for a faculty position (on any professorial level) in the area of Soft Materials. Of particular interest are polymers, colloids, biological systems, composites, or other complex materials comprising a "soft" phase. The successful candidate should have a strong experimental background and have an interest in understanding the fundamental interaction mechanisms in such materials. His/her research interests should range from nanoscopic to macroscopic length scales, and should take into account aspects of sustainability in the development of new materials. Industry experience would be an advantage.

It is expected that close collaborative relationships with other members of the Department will be established and that the candidate will teach both students of Materials Science at all levels and offer specialized courses for students of other disciplines (e.g. Physics, Chemistry, or Engineering). Undergraduate courses are taught in German or English, Master's degree courses are taught in English.

Please apply online at www.facultyaffairs.ethz.ch. Your application should include your curriculum vitae and a list of publications. The letter of application should be addressed to the President of ETH Zurich, Prof. Dr. Ralph Eichler. The closing date for applications is 30 April 2012. ETH Zurich is an equal opportunity and affirmative action employer. In order to increase the number of women in leading academic positions, we specifically encourage women to apply. ETH Zurich is also responsive to the needs of dual-career couples and is a family-friendly employer.

\section{I'VE SPECIALIZED FOR} 33 YEARS

in the placement of Metallurgical, Materials, and Welding Engineers in the areas of R\&D, Q.C. Production, Sales \& Marketing, nationwide. My background as a Met. Eng. can help you! Salaries to $\$ 190 K$. Fees paid by Co. Call/Send/Email Resume:

Michael Heineman, Meta-Find, Inc.;

P.O. Box 610525, Bayside, NY, 11361; Phone: (212) 867-8100;

E-mail: mikeh@meta-findny.com; Web: www.meta-findny.com

\section{JOM: Don't Miss An Issue!}

If you have not already done so, renew your TMS membership for 2012.

\section{Visit: members.tms.org}

This will ensure no interruption in receipt of your JOM subscription for 2012.

Remember that your TMS membership includes complete online access to JOM as well, including full-issue archives dating back to 1997.

Log in at members.tms.org and renew your membership now for 2012. Enjoy continued access to an array of additional benefits.

\section{A few examples are:}

- E-subscriptions to the Journal of Electronic Materials and Metallurgical and Materials Transactions $A$ and $B$

- Complimentary access to 20 additional journals/publications via Springerlink

- Discounts on Wiley publications

- Reduced registration fees for select TMS conferences 